\title{
ASPEK HUKUM DISKRIMINASI PADA ANAK AKIBAT PERCERAIAN
}

\author{
Hardian Iskandar S.H., M.H.
}

Fakultas Hukum Universitas Muhammadiyah Gresik

Jln. Sumatera 101 GKB (Gresik Kota Baru) Randuagung, Gresik 61121, Jawa

Timur

Email:Hardianiskan@umg.ac.id

\begin{abstract}
Children are the generation of the nation's administrators, whose growth is protected by the state. As the successor to a protected nation, children in essence need to be avoided from acts of discrimination from divorce that occur between parents so that the child's development and growth can develop both physically, mentally, and socially. This study discusses the legal aspects of discrimination in children based on divorce using the method of discussing normatives, to analyze how the legal aspects of confirmation of divorce children.
\end{abstract}

Keywords: Legal aspects, Discrimination, Children, Divorced

\section{Latar Belakang}

Anak merupakan suatu karunia yang diberikan Tuhan sekaligus juga merupakan generasi penurus bangsa sebagaimana diatur dalam Undangundang 1945 pasal 28B (2) dimana seorang anak berhak untuk dilindungi dari kekerasan maupun diskriminasi.

Berdasarkan hasil observasi yang dilakukan peneliti dalam analisis hukum mengeni fenomena diskriminasi anak akibat peceraian orang tua yang salah satu orang tua dalam keadaan mampu dan tidak melakukan penelantara 
apakah dapat dikenakan pidana. sehinnga dapat dijumapau beberapa masalah hukum yang perlu diketahui, yaitu : (1) kurangnya pemahaman akan diskriminasi dalam aturan hukum yang berlaku, (2) jenis yang dapat dipidana, (3) akibat hukum diskriminasi dan penyelesaiannya.

Berdasarkan hasil analisis mengenai diskriminasi anak akibat perceraian ini, sehingga timbul banyak penafsiran serta akibat hukum yang berlaku dari pendefinisian diskriminasi dalam Undang-undang perlindungan anak dimana anak tersebut merupakan hasil dari perceraian yang sah dan anak tersebut tidak dalam keadaan susah, mengalami kekerasa, dan pembullian apakah merupakan makna diskriminasi.

Masalah lain yang biasanya terjadi adalah penafsiran diskriminasi dalam aturan UU No. 35 Tahun 2014 tentang perubahan Atas UU No.23 Tahun 2002 tentang perlindungan anak. Dalam penerapan diskriminasi anak tersebut.

Berdasarkan permasalahan tersebut, perlu adanya suatu artikel atapun suatu bentuk hasil analisis pemahaman hukum guna meningkatkan sadar hukum akan hukum yang berlaku di indonesia. serta bertujuan untuk meningkatkan pemahaman hukum terhadap mahasiswa ataupun para ahli.

Dari uraian sebelumnya, maka peneliti mengatasi permasalahan yang terjadi pada penafsiran diskriminasi dengan judul "Aspek Hukum Diskriminasi Pada Anak Akibat Perceraian”.

\section{Rumusan Masalah}

1. Bagaimana aspek hukum dari perbuatan diskriminasi ?

2. Bagaimana perlindungan hukum diskriminasi terhadap anak akibat perceraian?

\section{Metode Penelitian}

Penelitian ini merupakan suatu penelitian hukum, sehingga metode yang digunakan adalah metode penelitian hukum yang dilakukan untuk mencari pemecahan masalah atas isu hukum dan permasalahan hukum yang ada, sehingga hasil dari penelitian hukum ini adalah memberikan preskripsi 
mengenai apa yang seyogyanya mengenai isu hukum yang diajukan serta dapat diterapkan dalam praktek hukum.

\section{Metode Pendekatan}

Metode Pendekatan yang akan digunakan adalah metode pendekatan yuridis 37ocial37ve, yakni penelitian difokuskan untuk mengkaji penerapan kaidahkaidah atau norma-norma dalam hukum positif, sebagai konsekuensi pemilihan 37ocia permasalahan hukum (hukum adalah kaidah atau norma yang ada dalam masyarakat) (Ibrahim:295).

Metode Pendekatan merupakan prosedur penelitian logika keilmuan hukum, maksudnya suatu prosedur pemecahan masalah yang merupakan data yang diperoleh dari pengamatan kepustakaan, data sekunder yang kemudian disusun, dijelaskan dan dianalisis dengan memberikan kesimpulan.(Ibrahim:57) Data yang digunakan adalah sebagai berikut :

a. Data sekunder merupakan data yang diperoleh melalui bahan kepustakaan.

b. Data primer, merupakan data yang diperoleh langsung dari masyarakat.Dalam penelitian 37ocial37ve, data primer merupakan data penunjung bagi data sekunder.(Hanitijo:10)\

\section{Hasil Dam Pembahasan}

\section{Aspek Hukum Perbuatan Diskriminasi}

Diskriminasi atau bahasa asing discrimination bisa diartikan merupakan sebuah tindakan membanding-bandingkan, adapun penjelasan diskriminasi menurut Kamus Besar Bahasa Indonesia (KBBI) adalah pembedaan perlakuan terhadap sesama warga negara. Dapaung penjelasan terkait definisi diskriminasi dapat kita temui dalam 39 tahun 1999 tentang Hak Asasi Manusia dalam pasal 1 angka 3 yang mengartikan setiap pembatasan, pelecehan, atau pengucilan yang langsung ataupun tak langsung didasarkan pada pembedaan manusia atas dasar agama, suku, ras, etnik, kelompok, golongan, status 37ocial, status ekonomi, jenis kelamin, bahasa, keyakinan politik, yang berakibat pengurangan, penyimpangan, atau penghapusan pengakuan, pelaksanaan, atau penggunaan hak asasi manusia 
dan kebebasan dasar dalam kehidupan baik individual maupun kolektif dalam bidang politik, ekonomi, hukum, 38ocial, budaya dan aspek kehidupan lainnya.. Dari penjelasan di atas maka dapat di klasifikiaskan beberapa jenis-jenis diskriminasi yang terdiri dari : Diskriminasi ras dan etnik, Diskriminasi jenis kelamin, Diskriminasi status dan ekonomi, Diskriminasi terhadap penyakit tertentu.

1. Diskriminasi ras dan etnik

Berdasar pada pasal 1 angka 1 Undang-undang Nomor 40 Tahun 2008 tentang penghapusan diskriminasi ras dan etnik mendefinisikan, Diskriminasi ras dan etnik adalah segala bentuk pembedaan, pengecualian, pembatasan, atau pemilihan berdasarkan pada ras dan etnis, yang mengakibatkan pencabutan atau pengurangan pengakuan, perolehan, atau pelaksanaan hak asasi manusia dan kebebasan dasar dalam suatu kesetaraan di bidang sipil, politik,ekonomi,38ocial dan budaya. Adapun tindakan yang dikategorikan sebagai diskriminasi etnik (pasla 1 angka 3) perbuatan yang berkenaan dengan segala bentuk pembedaan, pengecualian, pembatasan, atau pemilihan berdasarkan pada ras dan etnis, yang mengakibatkan pencabutan atau pengurangan pengakuan, perolehan, atau pelaksanaan hak asasi manusia dan kebebasan dasar dalam suatu kesetaraan di bidang sipil, politik, ekonomi, 38ocial, dan budaya.

2. Diskriminasi Jenis Kelamin

Berdasar pada Undang-Undang republic Indonesia Nomor 7 Tahun 1984 tentang pengesahan konvensi mengenai penghapusan segala bentuk diskriminasi terhadap wanita pasal 1 menjelaskan Mengesahkan Konvensi mengenai Penghapusan Segala Bentuk Diskriminasi terhadap Wanita (Convention on the Elimination of All Forms of Discrimination Against Women) yang telah disetujui oleh Majelis Umum Perserikatan BangsaBangsa pada tanggal 18 Desember 1979, dengan pensyaratan (reservation) terhadap Pasal 29 ayat (1) tentang penyelesaian perselisihan mengenai penafsiran atau penerapan Konvensi ini, yang salinannya dilampirkan pada Undang-undang ini. Turunan dari Undang -Undang ini salah satunya 
adalah terkait dengan Undang-undang nomor 13 tahun 2003 tentang ketenagakerjaan sebagaimana di atur dalam pasal 32 yang berbunyi (1)Penempatan tenaga kerja dilaksanakan berdasarkan asas terbuka, bebas, obyektif, serta adil, dan setara tanpa diskriminasi. (2) Penempatan tenaga kerja diarahkan untuk menempatkan tenaga kerja pada jabatan yang tepat sesuai dengan keahlian, keterampilan, bakat, minat, dan kemampuan dengan memperhatikan harkat, martabat, hak asasi, dan perlindungan hukum. (3) Penempatan tenaga kerja dilaksanakan dengan memperhatikan pemerataan kesempatan kerja dan penye diaan tenaga kerja sesuai dengan kebutuhan program nasional dan daerah. Terkait jenis kelamin ini di negara Indonesia sangat tegas dan menolak LGBT sebagai dasar pasal $28 \mathrm{~J}$ ayat (2) yang berbunyi Dalam menjalankan hak dan kebebasannya, setiap orang wajib tunduk kepada pembatasan yang ditetapkan dengan undangundang dengan maksud semata-mata untuk menjamin pengakuan serta penghormatan atas hak dan kebebasan orang lain dan untuk memenuhi tuntutan yang adil sesuai dengan pertimbangan moral, nilai-nilai agama, keamanan, dan ketertiban umum dalam suatu masyarakat demokratis.

3. Diskriminasi Status dan ekonomi

Penjelasan diskriminasi ini dapat di artikan bahwa dalam pemberian ataupun pelayanan baik pemerintah maupun masyarakat sekitar tidak dibolehkan memandang status ataupun tinggi rendahnya ekonomi yang mengakibatkan ketidak adilan pelayanan atau penerimaan.

4. Diskriminasi penyakit tertentu

Dalam diskriminasi ini dapat di artikan bahwa tidak diperbolehkannyanya membeda-bedakan atau mengucilkan suatu golongan,orang atau masyarakat dalam wilayah tertentu yang dikarenakan sebuah penyakit yang diderita. Sebagai contoh kasus covid 19 yang melanda negara sekarang ini terdapat penolakan suatu wilayah atau desa terhadap orang yang berstatus positif covid 19.

Diskriminasi dapat dikatakgorikan menjadi diskriminasi langsugn dan diskriminasi tidak langsung : 
a. Diskriminasi langsung

Yaitu yaitu perbuatan diskriminasi yang langsung ditujukan kepada ras,agama, atau golongan tertentu. Contoh : Sebuah lowongan kerja yang boleh mendaftar hanya orang dari ras tertentu.

b. Diskriminasi tidak langsung Yaitu suatu diskriminasi yang yang tidak tampak langsung tetapi terjadi. Contoh : contoh lowongan kerja yang menerapkan standar tinggi dengan menyebut syarat dengan ras tertentu.

\section{Perlindungan Diskriminasi pada Anak korban perceraian}

Undang-undang nomor 35 tahun 2014 tentang perubahan atas undangudang nomor 23 tahun 2002 tentang perlindungan anak pasal 1 angka 2 menjelaskan Perlindungan Anak ( selanjutnya disingkat UU perlindungan anak ) adalah segala kegiatan untuk menjamin dan melindungi Anak dan hak-haknya agar dapat hidup, tumbuh, berkembang, dan berpartisipasi secara optimal sesuai dengan harkat dan martabat kemanusiaan, serta mendapat perlindungan dari kekerasan dan diskriminasi. lebih lanjut dalam angka 12 hak anak adalah bagian dari hak asasi manusia yang wajib dijamin, dilindungi, dan dipenuhi oleh Orang Tua, Keluarga, masyarakat, negara, pemerintah, dan pemerintah daerah.

Perceraian sering terjadi dikarenakan factor-faktor tertentu baik factor ekonomi, ketidak cocokan, ataupun orang ke tiga, terlepas dari semua factor itu perlindungan anak harus dikedepankan dengan penerapan nondiskriminasi. Tanggung jawab terhadap anak masih merupakan kewajiban yang harus dilakukan suami dan istir walau sudah bercerai. Sebagaimana pasal 1 angka 1 yang mendifinisakan Anak adalah seseorang yang belum berusia 18 (delapan belas) tahun, termasuk anak yang masih dalam kandungan. Sehingga dapat di artikan anak yang dalam kandungan hingga usia delapan belas tahun harus dilindungi oleh kedua orang tua. Terkait perceraian dalam pasal 14 UU perlindungan anak ayat 1 Setiap Anak berhak untuk diasuh oleh Orang Tuanya sendiri, kecuali jika ada alasan dan/atau aturan hukum yang sah menunjukkan bahwa pemisahan itu adalah demi kepentingan terbaik bagi Anak dan merupakan pertimbangan 
terakhir, lebih lanjut dalam ayat 2 menjelaskan Dalam hal terjadi pemisahan sebagaimana dimaksud pada ayat (1), Anak tetap berhak:

a. bertemu langsung dan berhubungan pribadi secara tetap dengan kedua Orang Tuanya;

b. mendapatkan pengasuhan, pemeliharaan, pendidikan dan perlindungan untuk proses tumbuh kembang dari kedua Orang Tuanya sesuai dengan kemampuan, bakat, dan minatnya;

c. memperoleh pembiayaan hidup dari kedua Orang Tuanya; dan

d. memperoleh Hak Anak lainnya.

Dari bunyi pasal 14 ayat 2 diatas dijelaskan kewaiban-kewajiban orang tua setelah perceraian. Yang menjadi permasalah apabila poin dalam pasal 14 ayat 2 di langgar apakah dapat dikatakan diskriminasi kepada anak.

Sebagai landasan tindak lanjut larangan terhadap poin diatas dijelaskan dalam pasal UU Perlindungan anak pasal 76A yang berbunyi : Setiap orang dilarang:

a. memperlakukan Anak secara diskriminatif yang mengakibatkan Anak mengalami kerugian, baik materiil maupun moril sehingga menghambat fungsi sosialnya; atau

b. memperlakukan Anak Penyandang Disabilitas secara diskriminatif.

Yang apabila dilanggar maka sebagaimana di atur dalam pasal yang berbunyi 77 Setiap Orang yang melanggar ketentuan sebagaimana dimaksud dalam Pasal 76A dipidana dengan pidana penjara paling lama 5 (lima) tahun dan/atau denda paling banyak Rp100.000.000,0 (seratus juta rupiah). Dari runtutan pasal di atas untuk mencapai pembuktian orang tua yang bercerai melakukan diskriminasi harus ditinjau dari unsur-unsur itikat baik pasangan yang telah bercerai. Sebagai penafsiran pasal 14 ketika unsur anak sebagai mana penjelasan dalam UU perlindungan anak berkehendak tidak ingin bertemu dengan salah satu oang tua yang bercerai dan merasa tercukupi dengan ikut dalam salah satu orang tua serta tidak dalam tekanan bahkan sangat bahagia dengan kehidupannya bersama salah satu orang tua itu maka tidak bisa dikatakan sebuah 
diskriminasi. dikarenakan pada hakekatnya diskriminasi adalah membanding orang satu dengan orang lain, pandangan politik dll.

\section{Kesimpulan}

Dari hasil penelitian yang telah dibahas, maka dapat disimpulkan bahwa :

1. sangsi terhadap diskriminasi terhadap anak di ataur dalam pasal 77 yang berbunyi Setiap Orang yang melanggar ketentuan sebagaimana dimaksud dalam Pasal 76A dipidana dengan pidana penjara paling lama 5 (lima) tahun dan/atau denda paling banyak Rp100.000.000,0 (seratus juta rupiah).

2. Jika anak berkehendak tidak ingin bertemu dengan salah satu oang tua yang bercerai dan merasa tercukupi dengan ikut dalam salah satu orang tua serta tidak dalam tekanan bahkan sangat bahagia dengan kehidupannya bersama salah satu orang tua itu maka tidak bisa dikatakan sebuah diskriminasi.

Saran

1. Perlu di kedepannya restorative justice terkaid diskriminasi terhadap anak korban percraian.

\section{DAFTAR BACAAN}

\section{Buku :}

Maidin Gultom, 2008, Perlindungan Hukum terhadap Anak, Bandung:

Refika Aditama,.

Nazir, Moch. 2005. Metode penelitian Hukum. Bogor: PT Ghalia Indonesia.

Ibrahim, jhony. 2006. Theori dan Metodelogi Penelitian Hukum Normatif. Malang: PT Banyu Media

Soekamto, Soerjono. 2006 Penelitian Hukum Normatif. Jakarta: PT. Rajawali Pers

Soemitro, Tonny H. 1994. Metodologi penelitian hukum dan jurimetri. PT : Gali Indonesia

Undang-undang nomor 13 tahun 2003 tentang ketenagakerjaan

39 tahun 1999 tentang Hak Asasi Manusia 
Undang-Undang Nomor 35 Tahun 2014 tentang Perubahan Atas Undang-Undang Nomor 23 Tahun 2002 tentang Perlindungan Anak.

Kbbi.web.id

Pkh.kemsos.go.id 